\title{
Ameliorative Effects of Silicon Solublizers on Grain Qualities in Different Rice Genotypes (Oryza sativa L.)
}

\author{
Rakesh Sil Sarma* and Deepti Shankhdhar
}

Department of Plant Physiology, BHU, Varansi-221005, India

*Corresponding author

\begin{tabular}{|l|}
\hline Ke y w o r d s \\
Silicon, Protein, Grain \\
Quality etc. \\
\hline Article Info \\
\hline $\begin{array}{l}\text { Accepted: } \\
\text { 28 September } 2017 \\
\text { Available Online: } \\
\text { 10 November } 2017\end{array}$ \\
\hline
\end{tabular}

A B S T R A C T
A field experiment was conducted in kharif season of 2015 to investigate the influence of silicon solublizer on different rice genotypes namely PA-6129, PA-6201, PA-6444, PHB71, US-312, and BPT-5204. Soil application of silicon solubilizers was given at the time of maximum tillering, panicle initiation and 50\% flowering stage. The experiment was arranged as split plot design with three treatments and three replications. Various physiological and biochemical parameters mainly Total protein content $\left(\mathrm{mg} \mathrm{g}^{-1}\right.$ fresh weight), Amylose content (\%), iron and Zinc content (ppm) in grains, were evaluated at maturity stage. All rice genotypes showed the positive influence with silicon solublizers application which increase total protein $\left(\mathrm{mg} \mathrm{g}^{-1}\right.$ fresh weight), iron (ppm), zinc (ppm) content in grains, but negative influence in amylose content. The purpose of this study was to investigate whether the silicon solublizers influences the physiology, biochemistry of grains and its quality which ultimately increase yields in different rice genotypes. By using the silicon solublizers one would expect to raise the nutrition demand, yield quality many fold of rice and fulfilling the demand of overgrowing population in the upcoming years under severe climate change conditions.

\section{Introduction}

Rice (Oryza sativa L.) is the most widely consumed staple crop for a large part of the world's human population, especially in Asia. It accounts for $35-75 \%$ of caloric intake of more than 3 billion humans. Traditionally, countries in Asia have the largest share in world rice production with over 200 million metric tons. China is the world's leading rice producer $(30 \%$ of the world rice output), while India is occupied second position (22\%) with the largest area. Silicon is the eighth most common element by mass and second most abundant element in soil after oxygen. It plays important role on plant growth and crop production by preventing nutrient imbalances.
Deposition of silicon into soil and atmosphere can occur through silicon fertilizers, silica particles during floods, and rainfall. Silicon recycle occur through directly by reincorporation of straw and as manure after use as animal feed.

Silicon is an element which alone consistently present at concentration similar to those of the macro and secondary nutrients. Its concentration ranges from $0.1 \%$ (similar to $\mathrm{S}$ and $\mathrm{P}$ ) to more than $10 \%$ in whole plant dry matter (Epstein, 1999). The degree of silicon accumulation totally depends on uptake, translocation and transport mechanisms which 
significantly different in between crop species (Ma et al., 2001). In cereal crops and most dicots accumulates less than $0.5 \%$ Silicon in dry matter (Ma et al., 2008). Silicon mainly accumulated in leaves because it is distributed in the transpiration stream. In dried plant parts the silica bodies are located in silica cells below the epidermis and in epidermal appendices (Datnoff et al., 2003). Silicon can act as a physical barier in the leaf epidermal cells, which results a mechanism of defence, reduces lodging, increase photosynthesis capacity, reduce transpiration losses. Environmental conditions during grain filling influence the accumulation of protein in the developing rice grain and can alter the functional properties of the resulting flour. It was found that variations in protein content significantly modify grain quality (Falah et al., 2013). Treatment of rice plant with silica brought about activity of catalase and Glycine betaine (Roohizadeh et al., 2014). It was observed that the protein concentration increased in rice grain by increasing silicon concentration, three silicon aqueous solution $(0.25 \%, 0.50 \%$ and $1.00 \%)$ were applied in rice field as foliar spray and observation were recorded as maximum grain protein $(6.30 \%)$ was found in $0.50 \%$ silicon followed by $6.20 \%$ in $0.25 \%$ silicon solutions application, while the grain protein in $1.00 \%$ silicon application almost same as $0.25 \%$ silicon application. Ultimately it was concluded that these all rice grain protein content was higher than control $6.09 \%$ (Ahmad et al., 2013). In case of rice, silicon treatment increased the insoluble protein accumulation and decreased total soluble protein in different rice cultivars in drought condition (Emam et al., 2014). The proportion of amylose and amylopectin, are main component of starch which effect cooking quality of rice. Amylose is a linear polymer of a-(1/4) linked D-glucose units with few side chains. In contrast, amylopectin has many a-(1/6) linked glucoseside chains attached to the main a-(1/4) polymer. Regular grains contain about 20\% amylose while waxy grains contain a much lower percentage (Jang et al., 2007). The application of silicon can increased in the levels of total soluble carbohydrates, by effecting activity of photosynthetic apparatus (Iqbal et al., 2011). In sunflower, increasing the level of silicon it was observed that the sugar content was significantly increased as compared with control (without silicon treatment) (Zahoor $e t$ al., 2011).

It was reported that Zinc silicate deposited in the cell walls and it was directly involved in the detoxifi cation of $\mathrm{Zn}$. Photosynthesis is one of the most $\mathrm{Zn}$-sensitive plant processes, $\mathrm{Zn}$ adversely affect the photosynthetic electron transport chain. This effect could be due to metal-induced reductions in the levels of photosynthetic pigments, silicon play an important role in this process. Application of silicon can significantly increased photosynthetic activity under high zinc stress (Echarte et al., 2008). Si-increased mesophyll conductance, stomatal conductance, and play an important role in increasing rice tolerance to different abiotic and abiotic stress, ( $\mathrm{Gu}$ et al., 2012). Furthermore, the studies reveal that $\mathrm{Zn}^{+}$is required for the synthesis of IAA, and upon addition of $\mathrm{Si}$ in the growth medium, $\mathrm{Zn}$ content in plant increased. Hence, it is suggested that addition of $\mathrm{Si}$ might have increased IAA synthesis in plants by enhancing the $\mathrm{Zn}$ content, thus maintaining growth of plants under heavy metal $(\mathrm{Al}, \mathrm{Cd}$, Cr) stress (Tripathi et al., 2014). In rice it was observed, $\mathrm{Zn}$ content in grain might be due to the presence of increased amount of silicon solubilizers in soil solution which promote the availability of zinc in soil solution. The highest $\mathrm{Zn}$ content $67.03 \mathrm{mg} / \mathrm{kg}$ was observed for 5\% silicon application and lowest 52.77 $\mathrm{mg} / \mathrm{kg}$ was for $0 \%$ silicon. Furthermore, under the silixol treatment the expression levels of silicon transporter genes like, Os08g02630 (PsbY), Os05g48630 (PsaH), Os07g37030 
(PetC), Os03g57120 (PetH), Os09g26810 and Os04g38410 had significantly increased under high-Zn stress. Nevertheless, the addition of $1.5 \mathrm{mM} \mathrm{Si}$ increased the expression levels of these genes in plants under high-Zn stress at $72 \mathrm{~h}$, and the expression levels were higher in Si-treated plants than in $\mathrm{Si}$-deficient plants (Song et al., 2014). It has been reported that silicon increased iron transport from root to shoot. Increased expression of silicon transporter after silicon addition might influence iron uptake and translocation and benefits iron nutrient under deficient condition ( $\mathrm{Fu}$ et al., 2012). In corn plant it was reported that acquisition of iron by root increased when silicon was included in hydroponic solution (Gotardi et al., 2012). Plants under Fe deficiency significantly decreased $\mathrm{Fe}$ concentration in roots and shoots of soybean plants after 3 days of treatment conditions which concomitantly decreased more after 5 days of $\mathrm{Fe}$ deficiency (-Fe/-Si). The concentration of $\mathrm{Fe}$ was interestingly also observed highest in plants which were alone treated with $\mathrm{Si}$ (positive controls). The reduction of $\mathrm{Fe}$ concentration was observed more in roots compared to shoots (Pavlovic et al., 2014).

\section{Materials and Methods}

The field experiment was conducted at Dr Norman E. Borlaug Crop Research Centre, G. B. Pant University of Agriculture and Technology, Pantnagar (Uttarakhand), during kharif season of 2015. The purpose of study was to find the positive influence of silicon on growth, yields attributes in different rice genotypes (Oryza sativa L.). Different rice genotypes namely PA-6129, PA-6201, PA6444, PHB-71, US-312 and BPT-5204 were obtained from the Indian institute of Rice Research, Rajendranagar, Hyderabad. 10 gm solid dissolved in 2 litre water and make to 10 litre Sprayed it at different growing stage mainly in, maximum tillering, Panicle initiation, $50 \%$ flowering and milky grain stages. Protein, Amylose, Zinc and Iron content in grain was taken after harvest, this biochemical parameter is indicator of grain quality.

\section{Amylose content of grains}

Amylose content of grains was estimated in rice grain by using the method described by McCready and Owens, (1950).

\section{Standard curve}

Standard amylose solution ranging from 100$1000 \mu \mathrm{g}$ was taken in different clean and dry test tubes and $20 \mathrm{ml}$ distilled water was added and then three drops of phenolphthalein. After this, $0.1 \mathrm{~N} \mathrm{HCl}$ was added drop by drop until the pink color just disappeared. Then $1 \mathrm{ml}$ of iodine reagent was added and volume was made up to $50 \mathrm{ml}$ with distilled water and absorbance was recorded at $590 \mathrm{~nm}$ using dilute iodine reagent (dilute $1 \mathrm{ml}$ of iodine reagent to $50 \mathrm{ml}$ with distilled water) as blank. The standard curve was prepared and used for amylose estimation.

\section{Amylose extraction and estimation}

Rice grains were dehulled and grind with the help of pestle \& mortar. $500 \mathrm{mg}$ of powered sample was weighed, and $1 \mathrm{ml}$ of distilled ethanol was added followed by $10 \mathrm{ml}$ of $1 \mathrm{~N}$ $\mathrm{NaOH}$ and volume was made upto $50 \mathrm{ml}$ and left it for overnight. $2.5 \mathrm{ml}$ of the extract was taken and $20 \mathrm{ml}$ distilled water was added followed by three drops of phenolphthalein. After this, $0.1 \mathrm{NHCl}$ was added drop by drop until the pink colour just disappeared. Then 1 $\mathrm{ml}$ of iodine reagent was added and the volume was made upto $50 \mathrm{ml}$ and absorbance was recorded at $590 \mathrm{~nm}$ using dilute iodine reagent as blank. Amylose content was calculated by using standard. 
Protein content of grains was estimated by the method described by Bradford (1976). Standard curve

For preparing standard curve, firstly standard BSA solution ranging from 10 to $100 \mu 1$ was taken different test tubes and final volume was made up to $300 \mu$ with the help of distilled water. $3 \mathrm{ml}$ of Bradford dye was added in each test tube and its absorbance was recorded at $595 \mathrm{~nm}$. Standard curve was plot by placing concentration of BSA solution at $\mathrm{x}$-axis and absorbance at $\mathrm{y}$-axis.

\section{Protein extraction \& estimation}

Rice grains were dehusked and grind in mortar and pestle then add $500 \mathrm{mg}$ of rice grains were taken in $2.5 \mathrm{ml}$ of protein extraction buffer and centrifuged at $4^{0} \mathrm{C}$ at 10 , $000 \mathrm{rpm}$ for 15 minutes. $2 \mu \mathrm{l}$ supernatant was taken out in dry test tube and 2-3 drops of PMSF was added.300 $\mu 1$ extraction buffer was added in solution $300 \mathrm{ml}$ Bradford dye was added Absorbance was recorded at 595nm Protein content in the grains was measured by plotting the perpendicular on the standard curve.

\section{Micronutrient analysis}

Micronutrient such as Zinc and Iron were estimated from rice with the help of atomic absorption spectrometer (AAS) method was described by Singh et al., (1999).

\section{Iron and Zinc standard solutions}

\section{Procedure}

Rice grains were dehulled and ground with the help of pestle and mortar. 100mg of fine powder of rice was taken in the conical flask. Add $10 \mathrm{ml}$ of tri-acid mixture and kept for about 6-8 hours at a covered place for predigestion. After pre-digestion it was kept on the hot plate in the digestion chamber having fume exhaust system. Complete digestion was confirmed when the contents changes into colorless and only white residue appears. After digestion $5 \mathrm{ml}$ of $6 \mathrm{~N} \mathrm{HCl}$ was added in the sample. Volume was made up to $50 \mathrm{ml}$ with distilled water. Then it was filtered with the help of whatmann no. 42 filter paper into $50 \mathrm{ml}$ volumetric flask. Micronutrients were determined in the digested grain sample using atomic absorption spectrometer in respective wavelength.

\section{Results and Discussion}

\section{Total protein content (mg g-1 fresh weight)}

The total protein content in rice grain of all genotypes was also evaluated in silicon solubilizer treatment, it was show positive relation between silicon application and protein content. PA-6201 (17.62 mg g-1) showed maximum total protein content and the minimum in BPT-5204 (15.20 $\left.\mathrm{mg} \mathrm{g}^{-1}\right)$ under silicon solubilizer treatment. However silicon solubilizer showed maximum increase $(8.32 \%)$ in PA-6444 and minimum in $(0.77 \%)$ in BPT-5204 where compared to control. As compared to control (15.24 $\mathrm{mg} \mathrm{g}^{-1}$ fr. wt.) the overall mean of all genotypes showed increase protein content (16.22 $\mathrm{mg} \mathrm{g}^{-1} \mathrm{fr}$. wt.) under silicon solubilizer. The interaction between Treatment and genotypes was found statistically significant in respect to almost all the genotypes. The total protein content of PA-6201 was observed statistically significant with respect to all the genotypes as well as silicon solubilizer treatment. Siliconl application in soil positively influence the total protein content in different rice genotypes. After the silicon solubilizer in plants 0.77 to $8.32 \%$ increased total protein content was recorded. This was might be due to silicon treatment individually improved synthesis of different amino acids and enzymes in plants to overcome the stress. In 
wheat it was found that silicon can reduce the decomposition of total proteins at water stress (Ahmed et al., 2011).

\section{Amylose content (\%)}

Amylose content was recorded in rice grain after harvest of crops. Amylose content was significantly decreased after application of silicon solublizerin in rice grains.PA-6201 $(16.36 \%)$ showed maximum total amylose content and the minimum in US-312 (13.49\%) under silicon solubilizer treatment. However silicon solubilizer showed maximum decreased $(6.55 \%)$ in BPT-5204 and minimum $(1.50 \%)$ in PA-6201 where compared to control. As compared to control $(15.40 \%)$ the overall mean of all genotypes showed decreased amylose content (14.76\%) under silicon solubilizer the interaction between Treatment and genotypes was found statistically significant in respect to almost all the genotypes. Amylose content was significantly decreases in rice grain after soil application of silicon solubilizer. In solid treatment 1.50 to $6.55 \%$ decreased as compare to control. Silicon might be improved grain quality by decreasing amylose content and stickiness of grain. It might be cause formation of complex compound made by the reaction of silicon solubilizer with sugar molecules which inhibit amylase machinery. Increasing the level of silicon in sunflower it was observed that the sugar content was increased as well as amylase content was decreased (Zahoor et al., 2011).

Fig.1 Effect of silicon solubilizer on soluble protein content in seeds at different rice genotypes and vertical bars indicate \pm standard error of mean

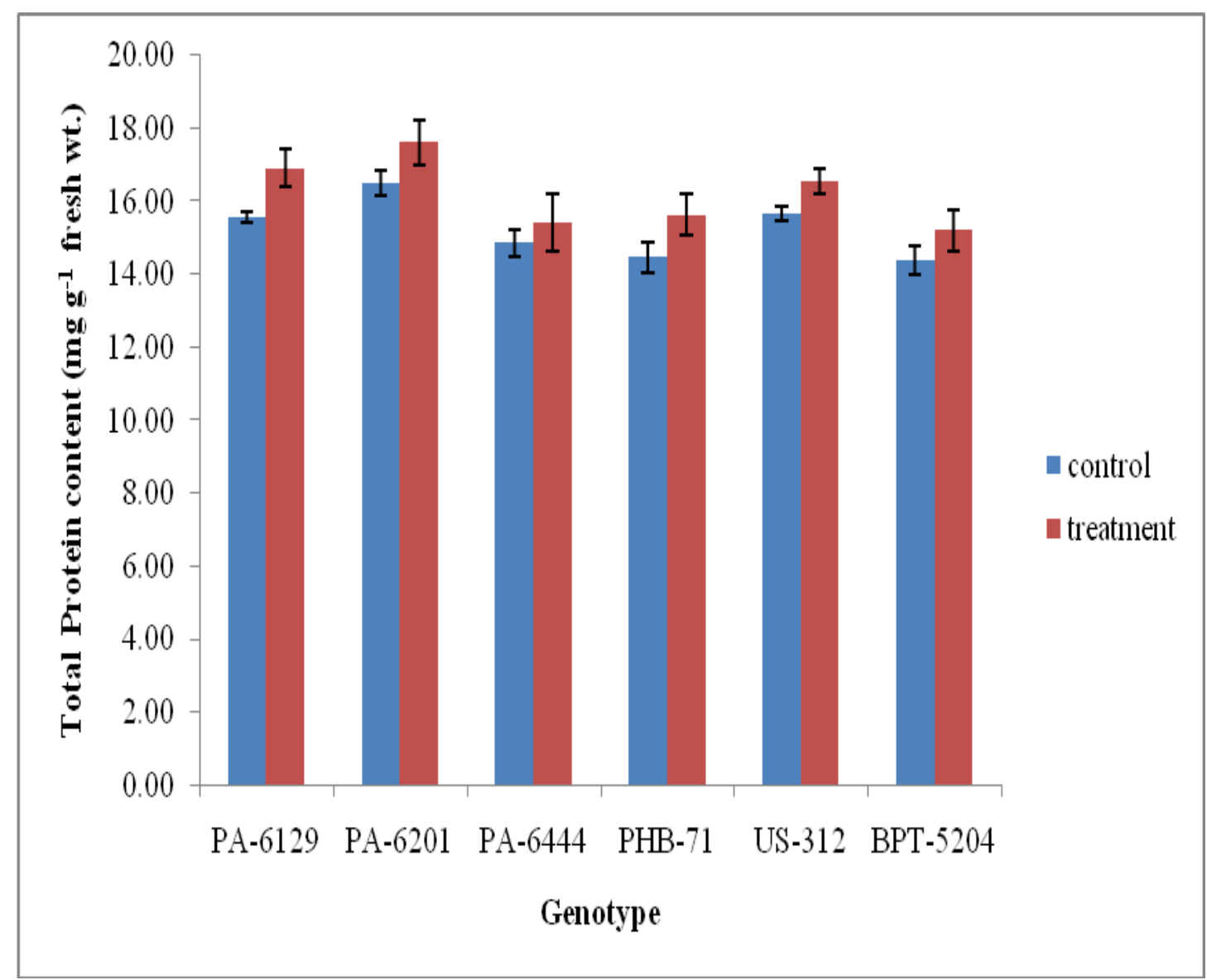


Fig.2 Effect of silicon solubilizer on amylose content in seeds at different rice genotypes and vertical bars indicate \pm standard error of mean

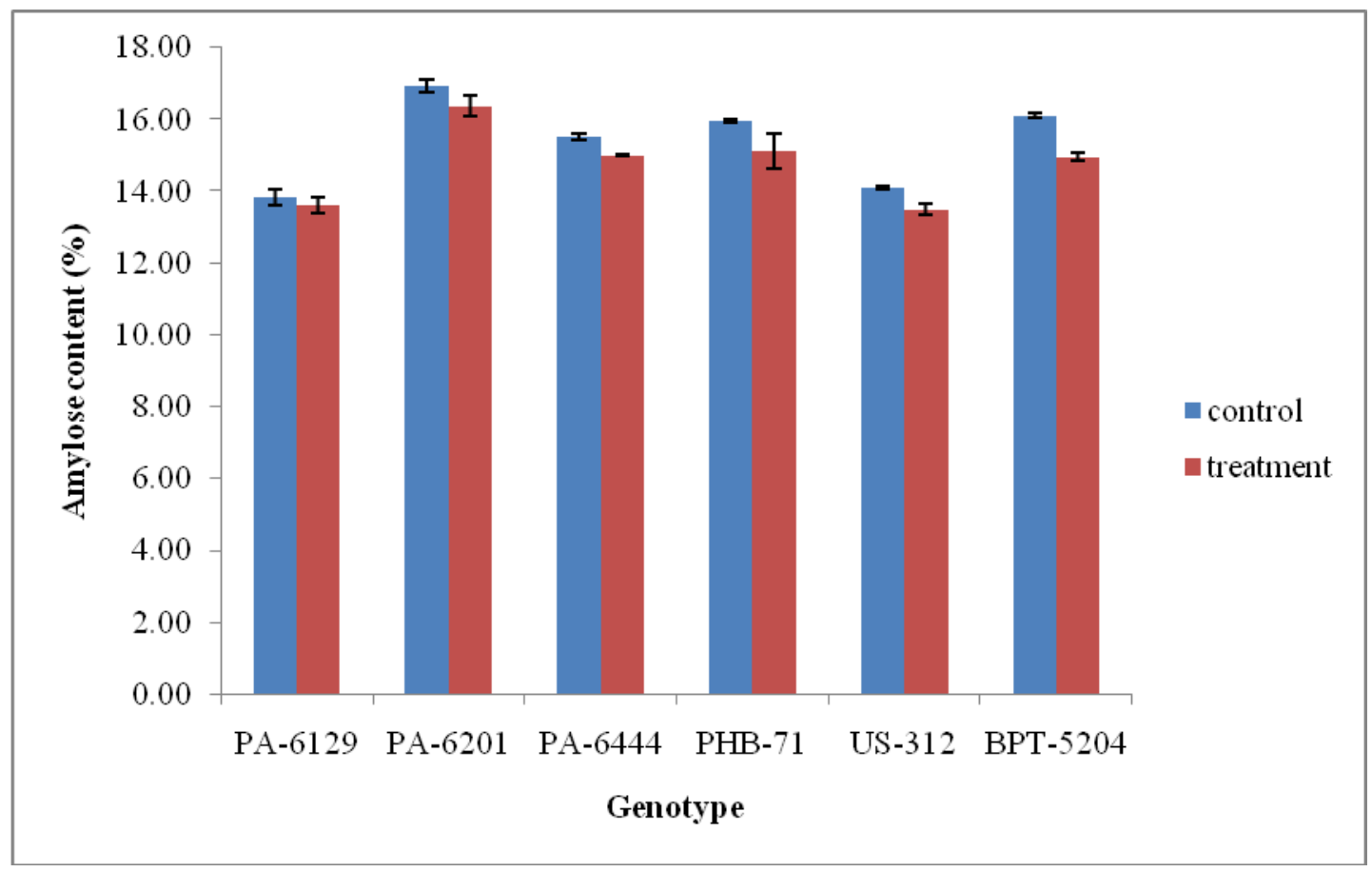

Fig.3 Effect of silicon solubilizer on iron content in grains at different rice genotypes and vertical bars indicate \pm standard error of mean

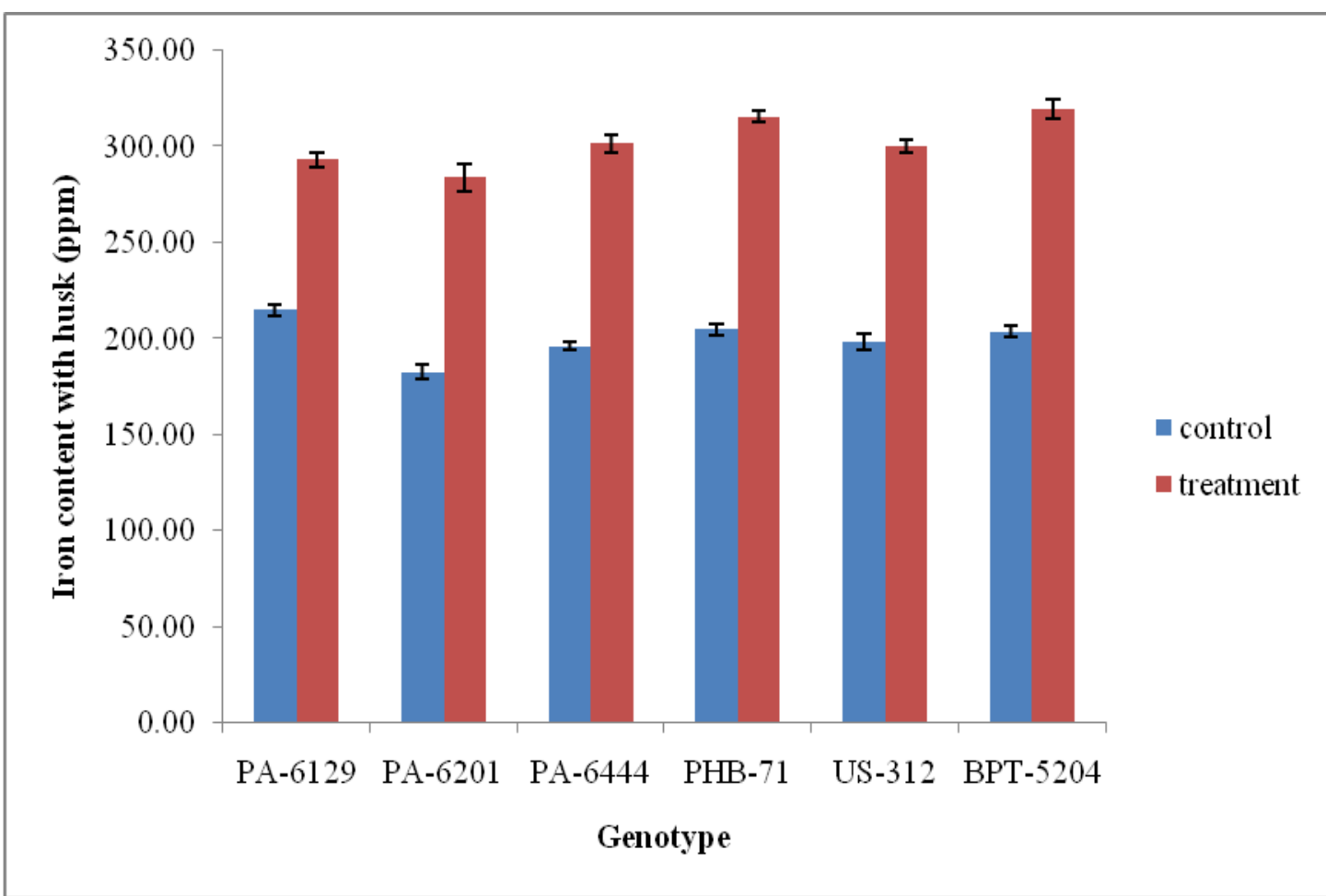


Fig.4 Effect of silicon solubilizer on iron content in seeds at different rice genotypes and vertical bars indicate \pm standard error of mean

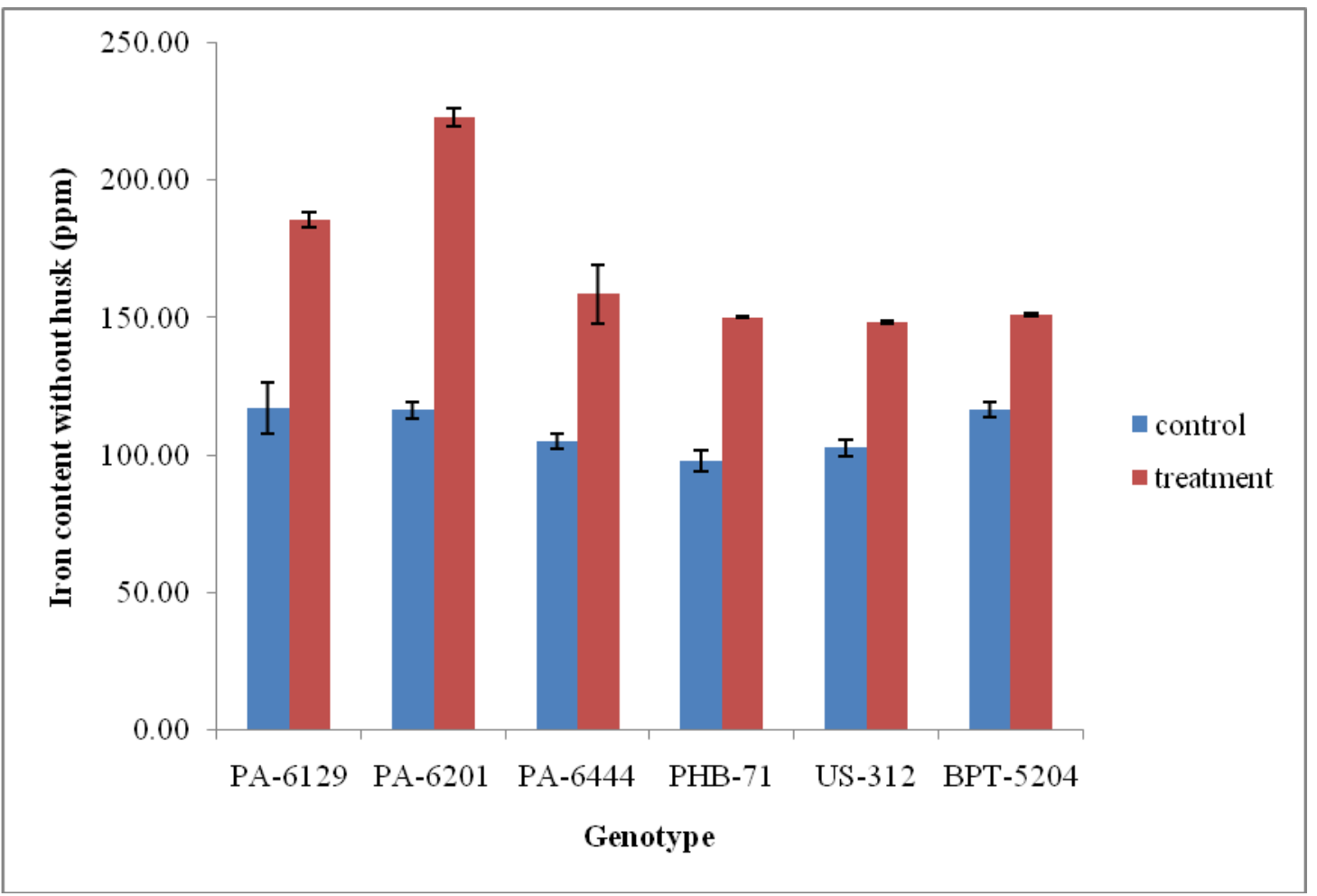

Fig.5 Effect of silicon solubilizer on zinc content in grains at different rice genotypes and vertical bars indicate \pm standard error of mean

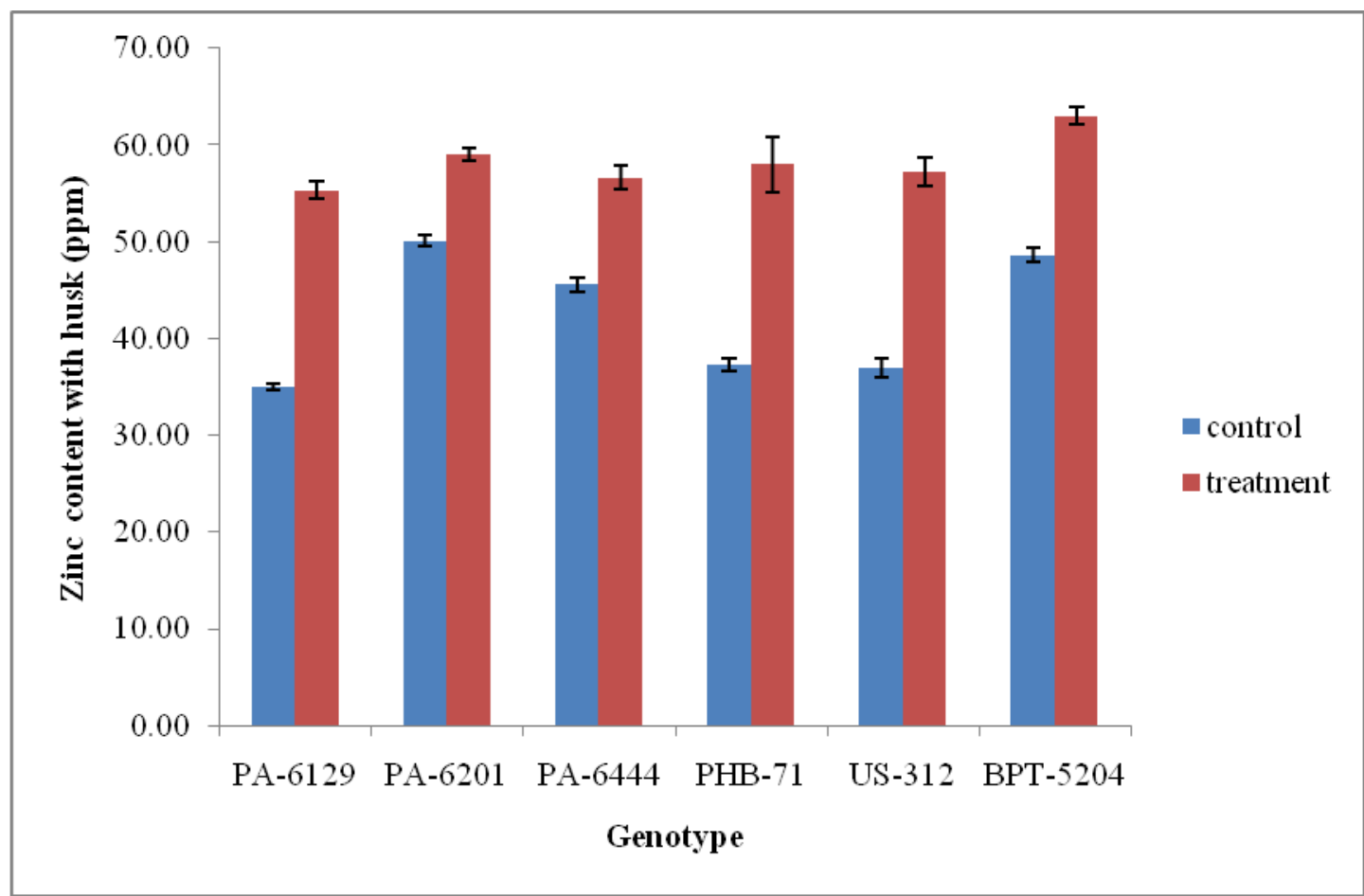


Fig.6 Effect of silicon solubilizer on zinc content in seeds at different rice genotypes and vertical bars indicate \pm standard error of mean

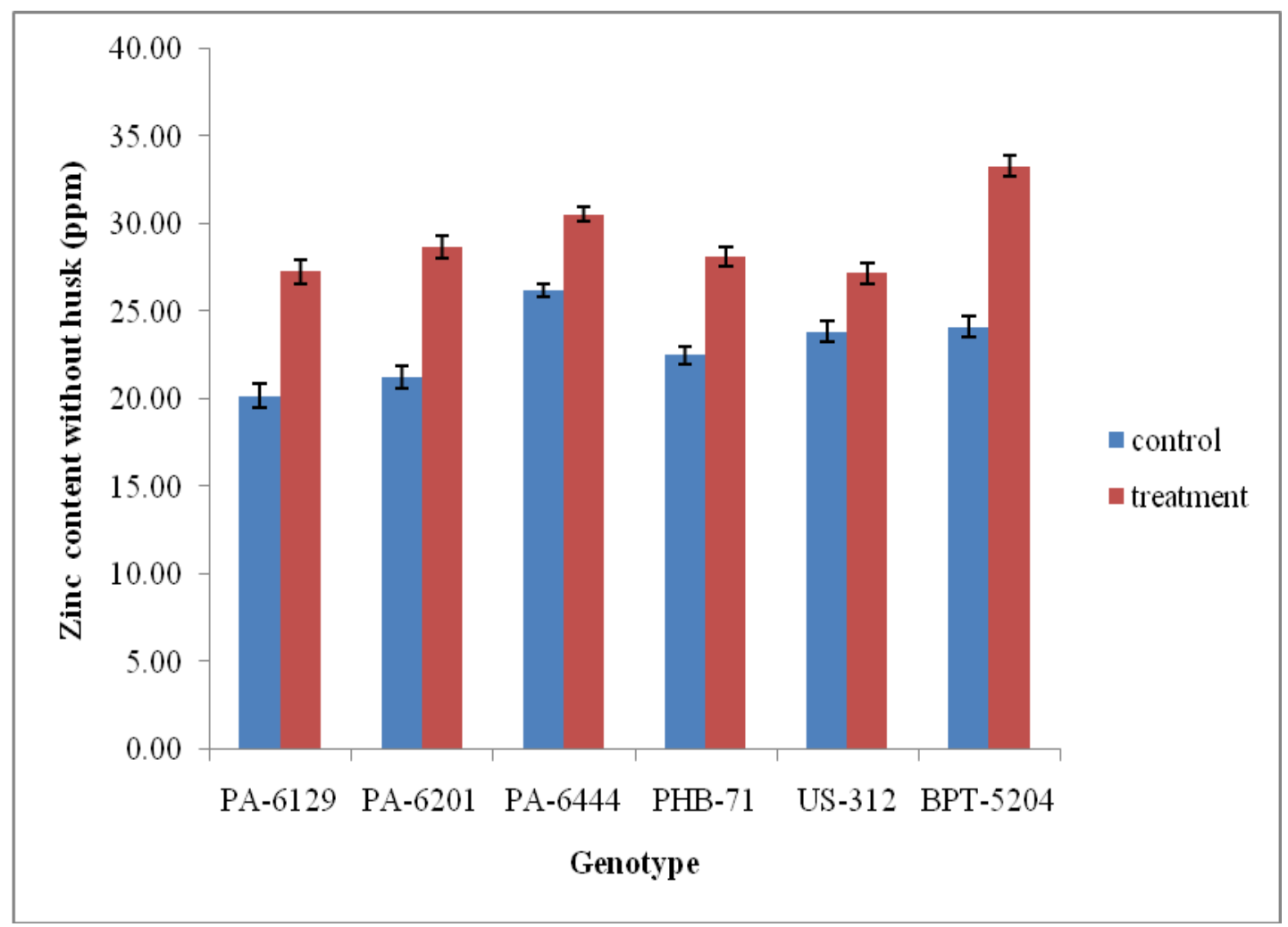

Table.1 Effect of silicon application on total protein content $\left(\mathrm{mg} \mathrm{g}^{-1}\right.$ fresh wt) and amylose content $(\%)$ in different rice genotypes

\begin{tabular}{|c|c|c|c|c|c|c|c|c|}
\hline \multirow[b]{2}{*}{$\begin{array}{l}\text { Name of } \\
\text { the rice } \\
\text { genotypes }\end{array}$} & \multicolumn{4}{|c|}{ Total protein content ( $\mathrm{mg} \mathrm{g}^{-1}$ fresh wt.) } & \multicolumn{4}{|c|}{ Amylose content (\%) } \\
\hline & Control & $\begin{array}{c}\text { Silicon } \\
\text { solubilizer } \\
\text { treatment }\end{array}$ & Mean & $\begin{array}{c}\% \\
\text { increase }\end{array}$ & Control & $\begin{array}{c}\text { Silicon } \\
\text { solubilizer } \\
\text { treatment }\end{array}$ & Mean & $\begin{array}{c}\% \\
\text { decrease }\end{array}$ \\
\hline PA-6129 & $15.58 \pm 0.15$ & $16.92 \pm 0.49$ & 16.25 & 7.08 & $13.84 \pm 0.22$ & $13.61 \pm 0.21$ & 13.72 & -4.22 \\
\hline PA-6201 & $16.49 \pm 0.34$ & $17.62 \pm 0.62$ & 17.05 & 2.90 & $16.93 \pm 0.17$ & $16.36 \pm 0.29$ & 16.64 & -1.50 \\
\hline PA-6444 & $14.85 \pm 0.38$ & $15.40 \pm 0.77$ & 15.12 & 8.32 & $15.52 \pm 0.08$ & $15.00 \pm 0.01$ & 15.26 & -2.53 \\
\hline PHB-71 & $14.46 \pm 0.41$ & $15.63 \pm 0.56$ & 15.04 & 2.42 & $15.94 \pm 0.04$ & $15.13 \pm 0.49$ & 15.54 & -4.82 \\
\hline US-312 & $15.67 \pm 0.19$ & $16.56 \pm 0.33$ & 16.11 & 3.37 & $14.09 \pm 0.05$ & $13.49 \pm 0.16$ & 13.79 & -4.00 \\
\hline $\begin{array}{l}\text { BPT- } \\
5204\end{array}$ & $14.38 \pm 0.38$ & $15.20 \pm 0.56$ & 14.79 & 0.77 & $16.10 \pm 0.06$ & $14.96 \pm 0.12$ & 15.53 & -6.55 \\
\hline \multirow[t]{2}{*}{ Mean } & 15.24 & 16.22 & & & 15.40 & 14.76 & & \\
\hline & Genotype (G) & $\begin{array}{l}\text { Treatment } \\
\text { (T) }\end{array}$ & & $\mathbf{T x V}$ & Genotype (G) & \multicolumn{2}{|c|}{$\begin{array}{l}\text { Treatment } \\
\text { (T) }\end{array}$} & TxV \\
\hline S.Em. \pm & 0.20 & 0.34 & & 0.49 & 0.08 & \multicolumn{2}{|c|}{0.13} & 0.19 \\
\hline$C D$ at $5 \%$ & 0.58 & 1.01 & & 1.44 & 0.23 & \multicolumn{2}{|c|}{0.40} & 0.57 \\
\hline
\end{tabular}


Table.2 Effect of silicon application on iron content ( $\mathrm{ppm}$ ) of rice grain with husk and without husk in different rice genotypes

\begin{tabular}{|c|c|c|c|c|c|c|c|c|}
\hline \multirow[b]{2}{*}{$\begin{array}{l}\text { Name of } \\
\text { the rice } \\
\text { genotypes }\end{array}$} & \multicolumn{4}{|c|}{ Iron content with husk (ppm) } & \multicolumn{4}{|c|}{ Iron content without husk (ppm) } \\
\hline & Control & $\begin{array}{c}\text { Silicon } \\
\text { solubilizer } \\
\text { treatment }\end{array}$ & Mean & $\begin{array}{c}\% \\
\text { increase }\end{array}$ & Control & $\begin{array}{c}\text { Silicon } \\
\text { solubilizer } \\
\text { treatment } \\
\end{array}$ & Mean & $\begin{array}{c}\% \\
\text { increase }\end{array}$ \\
\hline PA-6129 & $215.00 \pm 2.88$ & $293.33 \pm 3.75$ & 254.16 & 33.33 & $117.11 \pm 9.09$ & $185.69 \pm 2.96$ & 151.40 & 41.75 \\
\hline PA-6201 & $182.66 \pm 3.71$ & $284.00 \pm 7.37$ & 233.33 & 59.55 & $116.46 \pm 3.05$ & $223.11 \pm 3.46$ & 169.78 & 87.48 \\
\hline PA-6444 & $196.33 \pm 1.85$ & $301.66 \pm 4.40$ & 249.00 & 55.49 & $104.83 \pm 2.77$ & $158.75 \pm 10.68$ & 131.79 & 44.31 \\
\hline PHB-71 & $205.00 \pm 2.88$ & $315.66 \pm 2.96$ & 260.33 & 53.98 & $97.83 \pm 3.76$ & $150.23 \pm 0.39$ & 124.03 & 45.86 \\
\hline US-312 & $198.33 \pm 4.40$ & $300.00 \pm 3.46$ & 249.16 & 46.34 & $102.54 \pm 3.25$ & $148.30 \pm 0.65$ & 125.42 & 36.05 \\
\hline BPT-5204 & $203.66 \pm 3.17$ & $319.66 \pm 4.91$ & 261.66 & 59.03 & $116.50 \pm 2.56$ & $150.93 \pm 0.58$ & 133.71 & 27.91 \\
\hline \multirow[t]{2}{*}{ Mean } & 200.16 & 302.38 & & & 109.21 & 169.50 & & \\
\hline & Genotype (G) & \multicolumn{2}{|c|}{ Treatment $(T)$} & TxV & Genotype (G) & \multicolumn{2}{|c|}{ Treatment (T) } & TxV \\
\hline S.Em. \pm & 1.70 & \multicolumn{2}{|c|}{2.95} & 4.17 & 1.73 & \multicolumn{2}{|c|}{2.99} & 4.23 \\
\hline CD at $5 \%$ & 4.99 & \multicolumn{2}{|l|}{8.65} & 12.24 & 5.07 & \multicolumn{2}{|c|}{8.79} & 12.43 \\
\hline
\end{tabular}

Table.3 Effect of silicon application on zinc content (ppm) of rice grain with husk and without husk in different rice genotypes

\begin{tabular}{|c|c|c|c|c|c|c|c|c|}
\hline \multirow[b]{2}{*}{$\begin{array}{l}\text { Name of } \\
\text { the rice } \\
\text { genotypes }\end{array}$} & \multicolumn{4}{|c|}{ Zinc content with husk (ppm) } & \multicolumn{4}{|c|}{ Zinc content without husk (ppm) } \\
\hline & Control & $\begin{array}{c}\text { Silicon } \\
\text { solubilizer } \\
\text { treatment }\end{array}$ & Mean & $\begin{array}{c}\% \\
\text { increase }\end{array}$ & Control & $\begin{array}{c}\text { Silicon } \\
\text { solubilizer } \\
\text { treatment }\end{array}$ & Mear & $\begin{array}{c}\% \\
\text { increase }\end{array}$ \\
\hline PA6129 & $34.97 \pm 0.34$ & $55.35 \pm 0.83$ & 45.16 & 58.27 & $20.21 \pm 0.66$ & $27.30 \pm 0.34$ & 23.75 & 30.03 \\
\hline PA-6201 & $50.05 \pm 0.57$ & $59.05 \pm 0.63$ & 54.55 & 17.98 & $21.25 \pm 0.62$ & $28.68 \pm 0.23$ & 24.96 & 43.41 \\
\hline PA-6444 & $45.55 \pm 0.72$ & $56.66 \pm 1.16$ & 51.11 & 24.36 & $26.23 \pm 0.39$ & $30.57 \pm 0.82$ & 28.40 & 17.57 \\
\hline PHB-71 & $37.28 \pm 0.64$ & $58.04 \pm 2.85$ & 47.66 & 55.68 & $22.52 \pm 0.53$ & $28.18 \pm 0.72$ & 25.35 & 22.32 \\
\hline US-312 & $36.90 \pm 0.95$ & $57.18 \pm 1.43$ & 47.04 & 54.94 & $23.85 \pm 0.59$ & $27.23 \pm 0.34$ & 25.54 & 18.42 \\
\hline BPT-5204 & $48.63 \pm 0.68$ & $63.03 \pm 0.90$ & 55.83 & 29.60 & $24.16 \pm 0.60$ & $33.34 \pm 0.67$ & 28.75 & 44.98 \\
\hline \multirow[t]{2}{*}{ Mean } & 42.23 & 58.22 & & & 23.04 & 29.22 & & \\
\hline & \multirow{2}{*}{$\begin{array}{c}\text { Genotype (G) } \\
0.48\end{array}$} & \multicolumn{2}{|c|}{ Treatment $(\mathbf{T})$} & TxV & Genotype & \multicolumn{2}{|c|}{ Treatment $(\mathbf{T})$} & TxV \\
\hline S.Em. \pm & & \multicolumn{2}{|c|}{0.83} & 1.18 & 0.22 & \multicolumn{2}{|c|}{0.38} & 0.54 \\
\hline CD at $5 \%$ & 1.42 & \multicolumn{2}{|c|}{2.46} & 3.48 & 0.64 & \multicolumn{2}{|c|}{1.12} & 1.59 \\
\hline
\end{tabular}

\section{Iron content (ppm)}

The iron content in ppm was recorded in both grain with husk and without husk of rice after the thrashing of crops. In grains with husk, PHB-71 (315.66 ppm) showed maximum iron content and the minimum in PA-6201 (284.00 ppm) under silicon solubilizer treatment. However silicon solubilizer showed maximum increase $(59.55 \%)$ in PA-6201 and minimum $(33.33 \%)$ in PA-6129 where compared to control. As compared to control (200.16ppm) the overall mean of all genotypes showed increase iron content
(302.38 ppm) under silicon solubilizer. The interaction between Treatment and genotypes was found statistically significant in respect to almost all the genotypes. In grain without husk, Similarly PA-6201 (223.11 ppm) showed maximum iron content and the minimum in US-312 (148.30 ppm) under silicon solubilizer treatment. However silicon solubilizer showed maximum increase (87.48\%) in PA-6201 and minimum (27.91\%) in BPT-5204 where compared to control. As compared to control (109.21 ppm) the overall mean of all genotypes showed increase iron content $(169.50 \mathrm{ppm})$ under silicon 
solubilizer. The interaction between Treatment and genotypes was found statistically significant in respect to almost all the genotypes. Silicon solubilizerhad a significant influence on iron content in different rice genotypes. The iron content was found more in grain with husk, compared with dehusked grain under silicon treatment in soil as well as control condition which might be due that silicon can accumulate more heavy metal in husk compared to seeds. In solid treatment the iron content was significantly increased from 33.34 to $59.55 \%$ in grains with husk and 27.91 to $87.48 \%$ in seeds. It might be cause silicon solubilizer improves the iron transport from roots to grains, enhanced the activity of silicon transporter that influenced iron uptake and translocation in grains or seeds (Fu et al., 2012). Similar results were reported in cucumber and pumpkin, addition of silicon solution could mitigate iron deficiency in plants as compared with control (Bityutskii et al., 2013).

\section{Zinc content}

Zinc content was observed in both grain with husk and seeds without husk in ppm. In grains with husk, BPT-5204 (63.03 ppm) showed maximum Zinc content and the minimum in PA-6129 (55.35 ppm) under silicon solubilizer treatment. However silicon solubilizer showed maximum increase (58.27\%) in PA-6129 and minimum (17.98\%) in PA-6201 where compared to control. As compared to control $(42.23 \mathrm{ppm})$ the overall mean of all genotypes showed increase Zinc content (58.22 ppm) under silicon solubilizer. The interaction between treatment and genotypes was found statistically significant in respect to almost all the genotypes. In seeds BPT-5204 (33.34 ppm) showed maximum Zinc content and the minimum in US-312 $(27.23 \mathrm{ppm})$ under silicon solubilizer treatment. However silicon solubilizer showed maximum increase (44.98\%) in BPT5204 and minimum (17.57\%) in PA-6444 where compared to control. As compared to control $(23.04 \mathrm{ppm})$ the overall mean of all genotypes showed increase Zinc content (29.22 ppm) under silicon solubilizer. The interaction between Treatment and genotypes was found statistically non-significant in respect to all the genotypes. Silicon solubilizer had significant effect on Zinc content in different rice genotypes. The Zinc content was found more in grain with husk, compared with seeds under silicon treatment in soil as well as control condition. In solid treatment the Zinc content was significantly increased from 17.98 to $58.27 \%$ in grains with husk and 17.57 to $44.98 \%$ in seeds. The increment of in $\mathrm{Zn}$ content due to silicon solubilizer in soil might be improve the translocation and accumulation of zinc and other micro nutrients. Zinc is essential for auxin biosynthesis, in this point of view we can say silicon application in plants can improved plant hormone auxin biosynthesis. In case of rice it was found that highest Zinc content $(67.43 \mathrm{ppm})$ was found in under $5 \%$ silicon solubilizer application in soil as compared with control (Ghasemi et al., 2014).

In the overall conclusion, different biochemical parameters in grains i.e. protein content, Amylose content, micro nutrients Iron content and Zinc content were significantly increased in all of the genotypes by the application of Silicon solublizers,

This could be achieved by enhancing the plant physiological, and biochemical efficiency of converting photosynthates into biomass and partioning greater part of it to grains and ultimately increased grain quality. Different genes responsible for Iron and Zinc transport in plasmamembranes and vacuoler membranes (Tonoplast) could be further explored for its role in better growth and productivity to fulfilling the demand of overgrowing population in the upcoming years. 


\section{Acknowledgement}

The authors wish to thank Indian Institute of Rice Research, Hyderabad and All India Coordinated Rice Improvement Project of ICAR for providing the necessary facilities and funding for carrying out the present work.

\section{References}

Ahmad A., Afzal M., Ahmad A.U.H. and Tahir, M.2013. Effect of foliar application of silicon on yield and quality of rice (Oryza sativa L) $J$. Agron. 6:155-162.

Ahmed, M., Hassen, F.U., Qadeer, U. and Aslam, M.A. 2011. Silicon application and drought tolerance mechanism of sorghum. Afr. J. Agric Res. 6:594-607.

Bityutskii, N., Pavlovic, J., Yakkonen, K., Maksimovi, V. and Nikolic M. 2014. Contrasting effect of silicon on iron, zinc and manganese status and accumulation of metal-mobilizing compounds in micronutrient-deficient cucumber. Plant Physiol and Biochem. 74: 205-211.

Bradford, M.M., 1976. A rapid and sensitive method for the quantitation of microgram quantities of protein utilizing the principle of protein dye binding. Analytical. Biochem. 72: 248254.

Datnoff, L.E., Snyder, G.H. and Deran C.W. 2003. Influence of silicon fertilizer grade on blast and brown spot development in rice yields. Plant Dis. 76: 1182-1184.

Echarte, L., Rothstein, S. and Tollenaar, M. 2008. The response of leaf photosynthesis and dry matter accumulation to nitrogen supply in an older and a newer maize hybrid. Crop Sci. 48:656-665

Emam, M. M., Khattab, H. E., Helal, N. M. and Deraz, A. 2014. Effect of selenium and silicon on yield quality of rice plant grown under drought stress. A J Crop Sci. 8: 596-605.

Epstein, E.1999. Silicon Annu. Rev Plant Physiol Plant Mol. Biol. 50:641-664.

Fallah, A. 2013. Study of silicon and nitrogen effects on some physiological characters of rice. Intl. J. Agri. Crop Sci. 4: 238241.

Fu, Y.Q., Shen, H., Wu, D.M. and Cai, K.Z. 2012. Silicon-mediated amelioration of $\mathrm{Fe} 2$ ? toxicity in rice (Oryza sativa L.) roots. Pedosphere 22(6):795-802.

Ghasemi, M., Mobasser, H., Malidarreh, A. G. and Asadimanesh, H. 2010. Zinc, silicon and potassium application on rice. Int. J. Agri. Crop Sci. 5:936-942.

Gottardi, S., Iacuzzo, F., Tomasi, N., Cortella, G., Manzocco., L, Pinton., R, Romheld, V., Mimmo, T., Scanpicchio, M., Dalla, C. L and Cesco S. 2012. Beneficial effects of silicon on hydroponically grown corn salad (Valerianella locusta (L.) Laterr) plants. Plant Physiol. Biochem. 56: 14-23.

Gu, H.H., Zhan, S.S., Wang, S.Z., Tang, Y.T., Chaney, R. L., Fang, X.H., Cai, X.D. and Qiu, R.L.2011. Silicon-mediated amelioration of zinc toxicity in rice (Oryza sativa L.) seedlings.Plant Soil. 350: 193-204.

Iqbal, N., Khan, N. A. and Umar, 2011. Photosynthetic inhibition under salinity challenged environment: an insight into regulation of rubisco. Functional Genomics, Physiological Processes and Environmental Issues, p. 167.

Jang, S.W., Hamayun, M., Sohn. E.Y., Shin, D.H., Kim, K.U. and Lee IJ. 2007. Studies on the effect of silicon nutrition on plant growth, mineral contents and endogenous bioactive gibberellins of three rice cultivars. J. Crop Sci. Biotech. 10: 47-51.

Ma, J. F. and Yamaji N. 2008. Functions and transport of silicon in plants. A Review. 
Cell. Mol. Life Sci. 57: 1149 - 1153.

Ma, J.F., Miyake, Y. and Takahashi, E. 2001. Silicon as a beneficial element for crop plants. Silicon in Agriculture. Elsevier Science Publishing, New York, pp. 1739.

McCready, R. M. and Owens, H. S. 1950. A method for the extraction of amylose content in plants. Anal. Chem. 22: 1156.

Pavlovic, J., Samardzic, J., Maksimovic, V., Timotijevic, G., Stevic, N., Laursen, K.H., Hansen, T.H., Husted, S., Schjoerring, J.K., Liang, Y. and Nikolic, M. 2014. Silicon alleviates iron deficiency in cucumber by promoting mobilization of iron in the root apoplast. New Phytol. 198(4): 1096-1107.

Roohizadeh, G., Arbabian, S., Tajadod, G., Majd, A. and Salimpour, F. (2014). The study of Sodium silicate effects on the total protein content and the activities of catalase, Peroxidase and Superoxide Dismutase of Vicia faba L. Bull. Env.
Pharmacol. Life Sci. 3: 243-246.

Singh, V.P., Tripathi, D.K., Kumar, D. and Chauhan, D.K. 2011. Influence of exogenous silicon addition on aluminium tolerance in rice seedlings. Biol. Trace Elem. Res. 144: 1260-1274.

Song, A., Li, P., Li, P., Fan, F., Nikolic, M. and Liang, Y. 2014. The alleviation of zinc toxicity by silicon is related to zinc transport and antioxidative reaction in rice. Plant Soil, 344: 319-333

Tripathi, D.K., Singh, V.P., Gangwar, S., Prasad, S.M., Maurya, J. N. and Chauhan, D.K. 2014. Role of Silicon in Enrichment of Plant Nutrients and Protection from Biotic and Abiotic Stresses. Improvements of crops in the era of climatic changes. pp. 39-46.

Zahoor, M., Khaliq, R., Zafar, Z.U. and Athar, H.U.R. 2011. Degree of salt tolerance in some newly developed maize (Zea mays L.) varieties. African J. Bio. 8: 298-304.

\section{How to cite this article:}

Rakesh Sil Sarma and Deepti Shankhdhar. 2017. Ameliorative Effects of Silicon Solublizers on Grain Qualities in Different Rice Genotypes (Oryza sativa L.). Int.J.Curr.Microbiol.App.Sci. 6(11): 4164-4175. doi: https://doi.org/10.20546/ijcmas.2017.611.488 